\title{
INVESTIGATIONS OF THE CAPACITY OF SYNTHESIZING $3 \beta$-STEROLS IN MOLLUSCA-XIII. BIOSYNTHESIS AND COMPOSITION OF STEROLS IN SOME BIVALVES (ANISOMYARIA)
}

\author{
P. A. Voogt \\ Laboratory of Chemical Animal Physiology, The State University of Utrecht, 8 Padualaan, Utrecht, \\ The Netherlands
}

(Received 17 December 1973)

\begin{abstract}
The incorporation of sodium acetate-1- or $-2-{ }^{14} \mathrm{C}$ into some lipid classes of the anisomyarian bivalves Mytilus edulis, Atrina fragilis and Ostrea edulis was investigated.

2. It was demonstrated that the acetate was utilized for the biosynthesis of both saponifiable and non-saponifiable lipids.

3. Squalene could not be detected by means of gas-liquid chromatography.

4. Sterols were not synthesized by the animals during the experiments.

5. The sterol composition of the animals was determined. Sterols with 27 carbon atoms were the main ones (45-50 per cent), followed by those with 28 carbon atoms (35-37 per cent). Cholesterol and brassicasterol were quantitatively the most important sterols.
\end{abstract}

\section{INTRODUCTION}

MANY investigators have studied the sterols of Bivalvia. The reasons for this interest are quite obvious. First, the animals possess economic value, and second, at the time their sterols were considered to be a rich source of provitamin $\mathbf{D}$ and actually a great deal of the studies on bivalve sterols was initiated with the aim to indicate new sources of these provitamins. Results have been summarized in several reviews (Toyama, 1958; Bergman, 1962; Austin, 1970; Idler \& Wiseman, 1972; Voogt, 1972a). Unfortunately, most of these data are out of date and of little use because they were obtained before powerful separation and suitable identification techniques were available. Recent data have been given by Voogt (1972a). In the past few years interest in the sterols of bivalves has been increasing again (Idler \& Wiseman, 1971a). This has led to the discovery of several new sterols (Idler et al., 1970, 1971; Idler \& Wiseman, 1971b; Teshima et al., 1972).

Whereas our knowledge of the sterol composition in Bivalvia increased very fast, our knowledge of sterol metabolism is still very fragmentary and the results are difficult to interpret because they are contradictory.

Fagerlund \& Idler (1960) reported that radioactivity was present in digitonin-precipitable material from Mytilus californianus and Saxidomus giganteus after the injection of sodium acetate-2${ }^{14} \mathrm{C}$. Most activity was present in $\Delta^{5}$-monounsaturated sterols, with only traces in 24-methyl- enecholesterol (Fagerlund \& Idler, 1961b). They also found that Saxidomus giganteus was able to synthesize 24-methylenecholesterol from cholesterol (Fagerlund \& Idler, 1961b) and to introduce $\Delta^{22}$ and $\Delta^{25}$ double bonds (Fagerlund \& Idler, 1961a). From their study on the seasonal variations of the sterols of Placopecten magellanicus, Idler et al. (1964) concluded that in this animal metabolism and synthesis of cholesterol and 24-methylenecholesterol were interrelated. Tamura et al. (1964) obtained indications that Crassostrea is able to synthesize cholesterol and to convert this into 24methylenecholesterol. Thus all the results obtained by Idler and coworkers suggest that in bivalves there is an active sterol metabolism and that these animals are able to synthesize sterol(s). On the other hand, Salaque et al. (1966) reported that after incubation of Ostrea gryphea in either Lmethionine-5- ${ }^{14} \mathrm{C}$ or DL-mevalonic acid-2-14 $\mathrm{C}$, no radioactivity was present in the sterols. Walton \& Pennock (1972) concluded from their experiments that Cardium edule and Mytilus edulis were not able to synthesize sterols from DL-mevalonate-2-14 C.

In the scope of the long-term project of our laboratory on the biosynthesis of sterols in invertebrates, we started investigation of bivalves in 1966. Whereas, in the data mentioned above, there is no discrimination between reports on Anisomyaria or Eulamellibranchia (most reports are concerned with Anisomyaria), we decided to study both orders separately. This paper deals with some Anisomyaria, viz. Ostrea edulis, Mytilus edulis and Atrina fragilis. 
It contains the results of the experiments on their capacity of synthesizing sterols and further the sterol compositions determined by means of gas liquid chromatography.

\section{MATERIALS AND METHODS}

Specimens of Mytilus edulis were collected on old oysterbanks at Kattendijke (Zeeland, The Netherlands), those of Ostrea edulis were obtained from the Netherlands Institute of Sea Research at Texel, while those of Atrina fragilis were collected by fishermen of the Laboratory for Marine Biology Laboratoire Arago at Banyulssur-Mer, France.

The animals were each injected with an aqueous solution of either sodium acetate-1.14 $\mathrm{C}$ or sodium acetate-2-14C. Injections were given directly into the hepatopancreas (in the case of Atrina) or into the foot (in all other cases). In the experiment indicated Ostrea III animals were injected on the first, the third and the fifth day. The animals were incubated in running sea water for varying times and then killed. They were stored at $-20^{\circ} \mathrm{C}$ or fixed in ethanol until they were used. Data about the animals and the radioactive precursor administered are given in Table 1 .

Lipids were extracted from the animals using the procedure of Bligh \& Dyer (1959) with the lipids being saponified in a solution of $1.5 \mathrm{~N} \mathrm{KOH}$ in $80 \%$ methanol under the usual conditions. In the experiment called Ostrea I the animals were saponified in toto in this solution. Unsaponifiable and saponifiable lipids were isolated from the saponification mixture in the usual way. The unsaponifiable lipids were separated into a hydrocarbon fraction, a crude sterol fraction and a remaining fraction by means of column chromatography on alumina (Voogt, 1971a, b).

The hydrocarbon fraction was analysed on a Becker gas chromatograph, Model 1452 or 2300 . The glass columns $(180 \times 0.38 \mathrm{~cm}$ i.d. $)$ were filled with Chromosorb W (80-100 mesh, acid washed and silanized) coated with $1 \%$ SE-52. In addition, the hydrocarbon fraction was hydrogenated in iso-octane as described previously (Voogt, 1971b) and then chromatographed. Some carrier squalene was added to the hydrocarbon fraction and the squalene hexahydrochloride was prepared (Loud \& Bucher, 1968).

Sterols were isolated from the crude sterol fraction via their digitonides and purified by recrystallizing them from ethanol. Sterols of Ostrea III were also purified by means of thin-layer chromatography, sterols being chromatographed thrice on Silicagel $G$ using for development consecutively toluene-diethylether-ethanolacetic acid $(50: 40: 2: 0 \cdot 2$, by volume) di-isopropyletheracetic acid $(98: 2, \mathrm{v} / \mathrm{v})$ and toluene-ethylacetate $(4: 1$, $\mathrm{v} / \mathrm{v})$.

Gas chromatography and identification of the $3 \beta-$ sterols were performed as given elsewhere (Voogt, 1972b).

Radioactivity was determined in a Packard TriCarb-Liquid Scintillation Spectrometer, Model 3315. The scintillation medium consisted of toluene containing

Table 1. Data about some bivalves examined for their capacity of synthesizing sterols

\begin{tabular}{|c|c|c|c|c|c|c|}
\hline & \multicolumn{2}{|c|}{ Mytilus edulis } & \multirow{2}{*}{$\begin{array}{l}\text { Atrina } \\
\text { fragilis }\end{array}$} & \multicolumn{3}{|c|}{ Ostrea edulis } \\
\hline & $\mathbf{I}$ & II & & I & II & III \\
\hline Number of animals & 61 & 100 & 2 & 6 & 8 & 2 \\
\hline Date of collection & 26 April 1967 & 14 June 1968 & 21 June 1967 & 2 Feb. 1966 & 16 March 1966 & 25 Nov. 1966 \\
\hline $\begin{array}{l}\text { Radioactive pre- } \\
\text { cursor (specific } \\
\text { radioactivity) }\end{array}$ & $\begin{array}{l}\text { Sodium } \\
\quad \text { acetate-1-14 } \mathrm{C} \\
(21.6 \mathrm{mCi} / \mathrm{mM})\end{array}$ & $\begin{array}{l}\text { Sodium } \\
\quad \text { acetate-2-14 } \mathrm{C} \\
(2 \mathrm{mCi} / \mathrm{mM})\end{array}$ & $\begin{array}{l}\text { Sodium } \\
\text { acetate-1-14 } \mathrm{C} \\
(20 \mathrm{mCi} / \mathrm{mM})\end{array}$ & $\begin{array}{l}\text { Sodium } \\
\quad \text { acetate-1-14 } \mathrm{C} \\
(20 \mathrm{mCi} / \mathrm{mM})\end{array}$ & $\begin{array}{l}\text { Sodium } \\
\quad \text { acetate- } 1-^{14} \mathrm{C} \\
(20 \mathrm{mCi} / \mathrm{mM})\end{array}$ & $\begin{array}{l}\text { Sodium } \\
\quad \text { acetate-1-14 } \mathrm{C} \\
(20 \mathrm{mCi} / \mathrm{mM})\end{array}$ \\
\hline $\begin{array}{l}\text { Dose administered } \\
(\mu \mathrm{Ci})\end{array}$ & 3.5 & 1 & 25 & 25 & 25 & $3 \times 25^{*}$ \\
\hline Incubation time (hr) & 120 & 72 & 56 & $6 \cdot 5$ & $4 \cdot 5$ & 168 \\
\hline
\end{tabular}

* Explanation in text.

Table 2. Quantities and relative weights of the lipid fractions isolated from some bivalves

\begin{tabular}{|c|c|c|c|c|c|c|}
\hline & \multicolumn{2}{|c|}{ Mytilus edulis } & \multirow{2}{*}{$\begin{array}{l}\text { Atrina } \\
\text { fragilis }\end{array}$} & \multicolumn{3}{|c|}{ Ostrea edulis } \\
\hline & I & II & & I & II & III \\
\hline Fresh weight* (mg) & 354,000 & 392,000 & 92,000 & $295,700 \quad 2$ & $242,000 \quad 2$ & 210,000 \\
\hline Total lipids (mg); & 5091.7 & $6127 \cdot 7$ & $533 \cdot 2$ & $2799 \cdot 3 \dagger$ & 3321.5 & 8191.0 \\
\hline$\%$ fresh wt. & 1.44 & 1.56 & 0.58 & 0.95 & 1.37 & 3.90 \\
\hline Unsaponifiable lipids (mg); & $515 \cdot 5$ & $798 \cdot 0$ & $99 \cdot 7$ & $964 \cdot 7$ & $477 \cdot 1$ & $448 \cdot 0$ \\
\hline$\%$ fresh wt. & $0 \cdot 15$ & 0.20 & $0 \cdot 11$ & 0.33 & $0 \cdot 20$ & 0.21 \\
\hline Hydrocarbon fraction (mg) & $30 \cdot 0$ & $25 \cdot 3$ & $11 \cdot 2$ & & $18 \cdot 4$ & $19 \cdot 3$ \\
\hline Crude sterol fraction (mg) & 389.9 & 522.0 & $51 \cdot \overline{7}$ & $307 \cdot 2$ & $231 \cdot 2$ & $180 \cdot 0$ \\
\hline $3 \beta$-Sterols (mg); & $314 \cdot 2$ & $448 \cdot 6$ & 16.6 & $223 \cdot 9$ & $179 \cdot 1$ & $153 \cdot 6$ \\
\hline$\%$ fresh wt. & 0.09 & $0 \cdot 11$ & 0.02 & 0.08 & 0.07 & 0.07 \\
\hline
\end{tabular}

* Fresh weight, determined without the shells.

$\dagger$ Determined by summation of unsaponifiable and saponifiable lipids. 
Table 3. Radioactivity in the lipid fractions isolated from some bivalves after the injection of sodium acetate-1- or -2-11 $\mathrm{C}$ expressed in dis $\mathrm{min}^{-1} \mathrm{mg}^{-1}$

\begin{tabular}{|c|c|c|c|c|c|c|}
\hline & \multicolumn{2}{|c|}{ Mytilus edulis } & \multirow{2}{*}{$\begin{array}{l}\text { Atrina } \\
\text { fragilis }\end{array}$} & \multicolumn{3}{|c|}{ Ostrea edulis } \\
\hline & I & II & & I & II & III \\
\hline Total dosage administered (dis/min) & $4.74 \times 10^{8}$ & $2.22 \times 10^{8}$ & $1.11 \times 10^{8}$ & $3.33 \times 10^{8}$ & $4.44 \times 10^{8}$ & $3.33 \times 10^{8}$ \\
\hline $\begin{array}{l}\text { Total lipids } \\
\text { (incorporation as percentage of the } \\
\text { dosage administered) }\end{array}$ & & $\begin{array}{c}418 \cdot 5 \\
1 \cdot 16\end{array}$ & $\begin{array}{r}2581 \cdot 1 \\
1 \cdot 24\end{array}$ & & $\begin{array}{r}3450 \cdot 6 \\
2 \cdot 58\end{array}$ & $\begin{array}{r}1195 \cdot 0 \\
2.94\end{array}$ \\
\hline Saponifiable lipids & 4396 & $325 \cdot 0$ & $3570 \cdot 2$ & $819 \cdot 0$ & $4397 \cdot 3$ & $1430 \cdot 9$ \\
\hline Unsaponifiable lipids & $439 \cdot 0$ & $109 \cdot 9$ & 576.7 & & $2131 \cdot 3$ & $840 \cdot 8$ \\
\hline Hydrocarbon fraction & $40 \cdot 8$ & & $159 \cdot 2$ & $392 \cdot 0$ & $695 \cdot 0$ & 46.5 \\
\hline Crude sterol fraction & $106 \cdot 3$ & $51 \cdot 4$ & 99.9 & $26 \cdot 3$ & $886 \cdot 7$ & 258.7 \\
\hline $3 \beta$-sterols & $7 \cdot 6$ & $8 \cdot 4$ & 8.9 & $1 \cdot 1$ & $374 \cdot 0$ & $264 \cdot 8$ \\
\hline $3 \beta$-sterols after three recrystallizations & $\mathbf{7 \cdot 2}$ & $6 \cdot 2$ & $4 \cdot 1$ & $1 \cdot 4$ & $212 \cdot 7$ & $308 \cdot 0$ \\
\hline $3 \beta$-sterols after four recrystallizations & $6 \cdot 8$ & $5 \cdot 8$ & 0 & & 289.0 & $348 \cdot 3$ \\
\hline $3 \beta$-sterols after five recrystallizations & & & & & $325 \cdot 2$ & \\
\hline
\end{tabular}

$4 \mathrm{~g}$ 2,5-diphenyloxazole (PPO) and $50 \mathrm{mg}$ 1,4-di-2-(-5phenyloxazolyl)-benzene (POPOP) per litre (Hayes et al., 1956).

\section{RESULTS AND DISCUSSION}

The quantities of the isolated lipid fractions were determined and are given in Table 2. This table shows that generally the lipid contents in bivalves are low, ranging from 1.0 to about 1.5 per cent of the fresh weight. Very different values were found for Atrina and Ostrea III. The relative amounts of unsaponifiable lipids and $3 \beta$-sterols obtained for Atrina (Table 2) show that this animal is indeed poor in lipid, whereas the corresponding values obtained for Ostrea III are in good agreement with those of the other animals and suggest that the high lipid content in this case is due to the presence of saponifiable lipids, for example glycerides from the depot fat of the animals.

The specific radioactivity of each lipid fraction was determined and the results are shown in Table 3.

This table shows that incorporation of radioactivity into lipids is low. Even after the repeated injection of acetate in Ostrea III-finally to a dose of $75 \mu \mathrm{Ci}$ per animal and after an incubation time of $168 \mathrm{hr}$-incorporation of radioactivity into the lipids was no higher than 2.94 per cent. In all cases both saponifiable and non-saponifiable lipids were radioactive, allowing the conclusion that the animals are able to synthesize these lipids from acetate.

The hydrocarbon fractions were analysed on the stationary phase SE-52. In the chromatograms a series of peaks-probably representing a series of homologous hydrocarbons-was present, but squalene could not be detected, neither could squalane in chromatograms of the hydrogenated hydrocarbons. Some carrier squalene was added to the hydrocarbons remaining and squalene hexahydrochloride was prepared. This product appeared to be non-radioactive. This means that squalene was not synthesized under the experimental conditions.

Table 3 shows that in contrary to the sterols of Mytilus, Atrina and Ostrea I, those of Ostrea II and III are rather radioactive. The specific radioactivity of these sterols increased on recrystallization and had not yet reached a constant value even after four or five recrystallizations. At the same time, the melting point of the sterols decreased. The following melting points were observed for Ostrea II: after one recrystallization $136.3^{\circ} \mathrm{C}$, after two $129.3^{\circ} \mathrm{C}$, after three $128.7^{\circ} \mathrm{C}$ and after five $121.8^{\circ} \mathrm{C}$. This indicated that a radioactive component, which was not necessary a sterol, was enriched. For this reason the sterols of Ostrea III were also purified by means of thin-layer chromatography. The initial specific radioactivity amounted to $289 \mathrm{diss} / \mathrm{min}$ per mg. After chromatography in toluene-diethylether-ethanol-acetic acid specific radioactivity had decreased to 107 diss/min per mg. After an additional purification with tolueneethylacetate the specific radioactivity amounted to $75 \mathrm{diss} / \mathrm{min}$ per $\mathrm{mg}$ and after a third purification in disopropylether-acetic acid this value was $63 \mathrm{diss} / \mathrm{min}$ per $\mathrm{mg}$. This also confirmed that purification of the sterols of Ostrea was difficult. That is why the sterols were subjected to preparative gas-liquid chromatography (PGLC). Now radioactivity was eluated from the column before any of the sterols appeared. Further sterols were hydrogenated and their acetates purified via PGLC. This yielded the same results, viz. radioactivity was not concurrent with the sterols. From this it can be concluded that in Ostrea III, too, sterols are not radioactive. Sterols of Ostrea II were not available to subject them to PGLC, but it is 
reasonable to suppose that they would have shown the same picture.

Summarizing we can say that in our experiments no radioactivity was incorporated into sterols either from sodium acetate- $1-{ }^{14} \mathrm{C}$ or from sodium acetate-2- ${ }^{14} \mathrm{C}$ and that in Ostrea, where initially sterols were radioactive, finally radioactivity turned out to be not concomitant with the sterols. Thus our results are not consistent with those of Idler and coworkers, who concluded that biosynthesis of sterols occurred in Mytilus californianus and Crassostrea virginica but are in full agreement with those of Salaque et al. (1966). Yet we are not allowed to conclude that anisomyarian bivalves are not capable of synthesizing sterols because sterol biosynthesis may proceed at an extremely low rate in these animals. However, experiments of Idler and his coworkers lasted for a much longer time and even then mostly only indications for sterol biosynthesis were obtained.

A small amount of the sterols of each species was hydrogenated and after acetylation analysed on the stationary phase SE-30. In all chromatograms five peaks were present, representing sterols with a carbon content ranging from twenty-six to thirty carbon atoms. The proportional compositions of the sterols were calculated and are given in Table 4.

Table 4. Proportional composition, according to carbon content, of the hydrogenated steryl acetates of some bivalves

\begin{tabular}{lccccc}
\hline & $\mathrm{C}_{26}$ & $\mathrm{C}_{27}$ & $\mathrm{C}_{28}$ & $\mathrm{C}_{29}$ & $\mathrm{C}_{30}$ \\
\hline Mytilus edulis & $9 \cdot 0$ & $45 \cdot 0$ & 37.3 & 8.5 & 0.2 \\
Atrina fragilis & 3.7 & $50 \cdot 2$ & 35.7 & 9.7 & 0.8 \\
Ostrea edulis & $7 \cdot 5$ & 49.6 & 37.5 & $5 \cdot 2$ & 0.2 \\
\hline
\end{tabular}
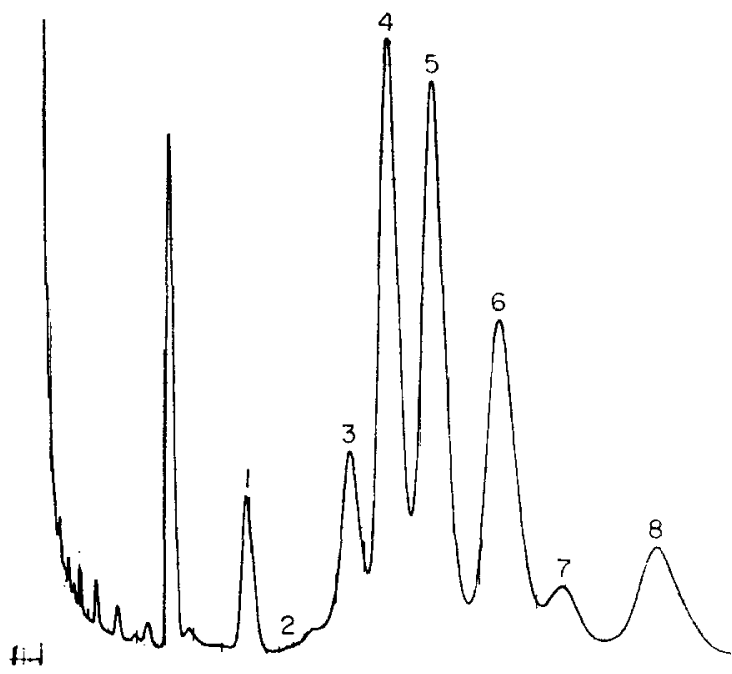

Fig. 1. Chromatogram of TMS derivates of the sterols of Mytilus edulis after GLC separation on the stationary phase SE-30. The percentage composition and the steroid number of each sterol are given. The steroid numbers of the suitable sterols are given in parentheses. 1. $5.9 \% \mathrm{C}_{20}$ sterol $28 \cdot 54 ; 2$. $12 \cdot 7 \%$ 22-dehydrocholesterol $29.85(29.80) ; 3.35 .9 \%$ cholesterol $30.21(30 \cdot 18)$; 4. $31.5 \%$ brassicasterol $30.58(30.58)$ or desmosterol $(30.50) ; 5$. 9.9\% campesterol 31.11 (31.19) or 24methylenecholesterol $(31.07) ; 6.1 .5 \%$ stigmasterol $31.52(31 \cdot 50) ; 7.2 \cdot 3 \% \beta$-sitosterol $32.06(32.04)$ or 28 isofucosterol (32.02).

The sterols were analysed on the stationary phases SE-30 and NPGS as their trimethylsilylethers. Chromatograms of the three species resembled each other very closely. For this reason only representative chromatograms of Mytilus are depicted (Figs. 1 and 2). The proportional com-

Table 5. Proportional composition of the sterols of some bivalves

\begin{tabular}{|c|c|c|c|}
\hline Sterols & Mytilus edulis & Atrina fragilis & Ostrea edulis \\
\hline $\mathrm{C}_{26}$ sterols & $5 \cdot 0^{*}$ & $3 \cdot 6^{*}$ & $7 \cdot 5^{*}$ \\
\hline $\begin{array}{l}\text { 22-cis-Cholesta-5,22-dien-3 } \beta \text {-ol } \\
\text { 22-trans-Cholesta-5,22-dien-3 } \beta \text {-ol } \\
\text { Cholest-5-en-3 } \beta \text {-ol } \\
\text { Cholesta-5,24-dien-3 } \beta \text {-ol }\end{array}$ & $\begin{array}{r}1 \cdot 0 \\
9 \cdot 0 \\
34 \cdot 0 \\
10 \cdot 5\end{array}$ & $\begin{array}{r}7 \cdot 8 \\
11 \cdot 2 \\
31 \cdot 1 \\
0 \cdot 9\end{array}$ & $\begin{array}{r}3 \cdot 6 \\
11 \cdot 6 \\
33 \cdot 2 \\
?\end{array}$ \\
\hline $\begin{array}{l}\text { 24-Methyl-cholesta-5,22-dien-3 } \beta \text {-ol } \\
\text { 24-Methyl-cholest-5-en-3 } \beta \text {-ol } \\
\text { 24-Methylenecholest-5-en-3 } \beta \text {-ol }\end{array}$ & $\begin{array}{r}21 \cdot 5 \\
3 \cdot 0 \\
9 \cdot 0\end{array}$ & $\begin{array}{r}23 \cdot 2 \\
1 \cdot 8 \\
7 \cdot 3\end{array}$ & $\begin{array}{r}24 \cdot 7 \\
2 \cdot 6 \\
9 \cdot 5\end{array}$ \\
\hline $\begin{array}{l}\text { 24-Ethyl-cholesta-5,22-dien-3 } \beta \text {-ol } \\
\text { 24-Ethyl-cholest-5-en-3 } \beta \text {-ol } \\
\text { 24-Ethylidenecholest-5-en-3 } \beta \text {-ol }\end{array}$ & $\begin{array}{l}3 \cdot 0 \\
3 \cdot 5 \\
0 \cdot 3\end{array}$ & $\begin{array}{l}2 \cdot 7 \\
5 \cdot 1 \\
-\end{array}$ & $\begin{array}{l}1 \cdot 5 \\
3 \cdot 4 \\
1 \cdot 7\end{array}$ \\
\hline Unidentified & $0 \cdot 3$ & $5 \cdot 4$ & $0 \cdot 4$ \\
\hline
\end{tabular}

* Two components. 


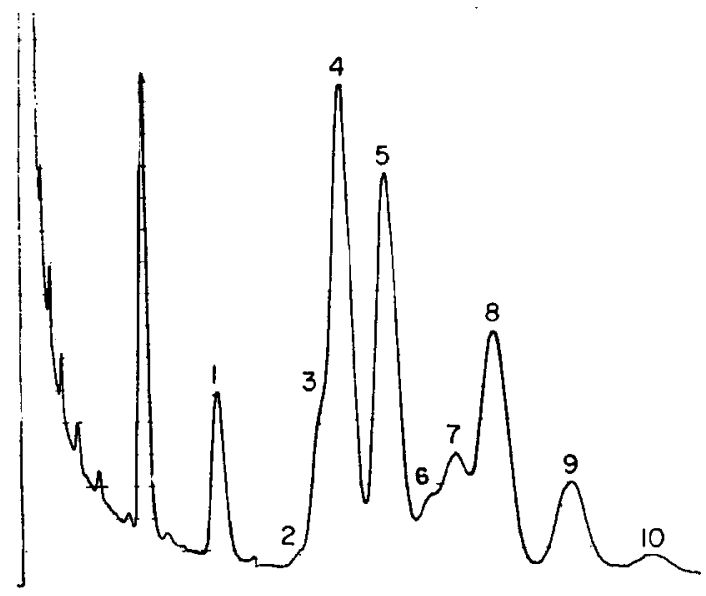

Fig. 2. Chromatogram of TMS derivatives of the sterols of Mytilus edulis after GLC separation on the stationary phase NPGS. The percentage composition and the steroid number of each sterol are given. The steroid numbers of the suitable sterols are given in parentheses. 1. $4.8 \% \mathrm{C}_{26}$ sterol $28.60 ; 2$. $1.0 \%$ 22-cis-dehydrocholesterol $29 \cdot 87$ (29.92); 3. 8.7\% 22-trans-dehydrocholesterol $30.10(30.09) ; 4$. $33.0 \%$ cholesterol 30.34 (30.36); 5 . $21.5 \%$ brassicasterol $30 \cdot 77(30 \cdot 83) ; 6.13 \cdot 5 \%$ desmosterol $31.28(31 \cdot 15)$ or campesterol (31.43); 7 . 12.0\% 24methylenecholesterol $31.72 \quad(31.67)$ or stigmasterol $(31.72)$; 8. 4.0\% $\beta$-sitosterol 32.25 (32.29); 9. $0.3 \%$ 28isofucosterol $32 \cdot 78(32 \cdot 79)$.

position of the sterols was calculated and is summarized in Table 5 .

Tables 4 and 5 show the strong resemblance in the sterol composition of these bivalves, desmosterol being the sole component which is present in widely different amounts. The composition of Mytilus is in good agreement with that of Mytilus edulis given by Idler \& Wiseman (1971), although the latter authors do mention some lesser components with 28 and 29 carbon atoms. The $\mathrm{C}_{26}$ sterols given in Table 5 probably are identical with 22-cis- and 22-trans-24-norcholesta-5,22-dien-3B-ol. Possibly trace amounts of desmosterol are present in Ostrea edulis. In each of the three species (mostly) a minor component was present that could not be identified. It is striking that in bivalves $\mathrm{C}_{27}$ sterols do not hold the predominant position that they have in most other molluscs. Especially has cholesterol, which in most other molluscs makes up for over 50 per cent of the total sterols, become less predominant. At the same time brassicasterol has become more important. This suggests that brassicasterol might replace cholesterol in some of it functions. In general, we can say that in comparison to other molluscs there is a strong shift from mono-unsaturated sterols towards di-unsaturated ones. It would be interesting to know whether this phenomenon is related to the high content of polyunsaturated fatty acids in bivalves (Voogt, 1972a).

\section{REFERENCES}

AUSTIN J. (1970) The sterols of marine invertebrates and plants. In Advances in Steroid Biochemistry and Pharmacology (Edited by Briggs M. H.), Vol. 1, pp. 73-96. Academic Press, New York.

BergmanN W. (1962) Sterols: their structure and distribution. In Comparative Biochemistry (Edited by FlorkIN M. and MASON S.), Vol. 3, pp. 103-162. Academic Press, New York.

BLIGH E. G. \& Dyer W. J. (1959) A rapid method of total lipid extraction and purification. Can.J. Biochem. Physiol. 37, 911-917.

Fagerlund U. H. M. \& IDler D. R. (1960) Marine sterols-VI. Sterol biosynthesis in molluscs and echinoderms. Can. J. Biochem. Physiol. 38, 997-1002.

FAGERLUND U. H. M. \& IDLeR D. R. (1961a) Marine sterols-VIII. In vivo transformations of the sterol side chain by a clam. Can. J. Biochem. Physiol. 39, 505-509.

FAGerLund U. H. M. \& IDLeR D. R. (1961b) Marine sterols-IX. Biosynthesis of 24-methylenecholesterol in clams. Can. J. Biochem. Physiol. 39, 1347-1355.

Hayes F. N., Rogers B. S. \& Langham W. H. (1956) Counting suspensions in liquid scintillators. Nucleonics 14, 48-51.

IdLeR D. R., SAFE L. M. \& MacDonald E. F. (1971) A new C-30 sterol (Z)-24-propylidenecholest-5-en-3 $\beta$-ol (29-methylisofucosterol). Steroids 18, 545-553.

IdLer D. R., Tamura T. \& WainaI T. (1964) Seasonal variations in the sterol, fat and unsaponifiable components of scallop muscle. J. Fish Res. Bd Can. 21, 1035-1042.

IDLER D. R. \& WiSEMAN P. (1971a) Sterols of molluscs. Int. J. Biochem. 2, 516-528.

IDLER D. R. \& WISEMAN P. (1971b) Identification of 22-cis-cholesta-5,22-dien-3 $\beta$-ol and other scallop sterols by gas-liquid chromatography and mass spectrometry. Comp. Biochem. Physiol. 38A, 581-590.

IDLER D. R. \& Wiseman P. (1972) Molluscan sterols: a review. J. Fish. Res. Bd Can. 29, 385-398.

Idler D. R., Wiseman P. M. \& Safe L. M. (1970) A new marine sterol, 22-trans-24-norcholesta-5,22-dien$3 \beta$-ol. Steroids 16, 451-461.

LOUD A. V. \& BuCHER N. L. R. (1958) The turnover of squalene in relation to the biosynthesis of cholesterol. J. biol. Chem. 233, 37-41.

Salaque A., Barbier M. \& Lederer E. (1966) Sur la biosynthèse des stérols de l'huître (Ostrea gryphea) et de l'oursin (Paracentrotus lividus). Comp. Biochem. Physiol. 19, 45-51.

Tamura T., Truscott B. \& IdLer D. R. (1964) Sterol metabolism in the oyster. J. Fish. Res. Bd Can. 21, 1519-1522.

Teshima S., Kanazawa A. \& Ando T. (1972) A $C_{26}$-sterol in the clam, Tapes phillippinarum. Comp. Biochem. Physiol. 41B 121-126.

ToYama Y. (1958) Die Sterine der fetten Öle von wirbellosen Wassertieren. Fette Seifen Anstrichmittel 60, 909-915.

VoOGT P. A. (1971a) Investigations of the capacity of synthesizing $3 \beta$-sterols in Mollusca-V. The biosynthesis and composition of $3 \beta$-sterols in the mesogastropods Crepidula fornicata and Natica cataena. Comp. Biochem. Physiol. 39B, 139-149. 
Voogt P. A. (1971b) The biosynthesis of $3 \beta$-sterols and identification of 3 3 -sterols. In Experiments in Physiology and Biochemistry (Edited by KERKUT G.), Vol. 4, pp. 1-33. Academic Press, New York.

Voogt P. A. (1972a) Lipid and sterol components and metabolism in mollusca. In Chemical Zoology (Edited by Florkin M. \& Scheer B. T.), Vol. 7, pp. 245-300. Academic Press, New York.

Voogt P. A. (1972b) Analysis of the sterols of the pulmonates Arion rufus, Arianta arbustorum, and Succinea putris. Neth. J. Zool. 22, 489-496.
Walton M. J. \& PenNock J. F. (1972) Some studies on the biosynthesis of ubiquinone, isoprenoid alcohols, squalene and sterols by marine invertebrates. Biochem. J. 127, 471-479.

Key Word Index-Sterol biosynthesis in molluscs; sterols of bivalves; Mytilus edulis; Atrina fragilis; Ostrea edulis. 